\title{
Study on the Comprehensive Evaluation of Economical Sustainable Development of Mining City*
}

\author{
Baoquan Ning \\ Department of Mathematics \\ Liupanshui Normal University \\ Liupanshui, China 553004
}

\author{
Zhenpei Shan \\ Department of Mathematics \\ Liupanshui Normal University \\ Liupanshui, China 553004
}

\begin{abstract}
This paper constructs an index system of economic sustainable development of mining city including 6 dimensions of economic scale, industrial structure, economic intensiveness, economic extroversion, economic driving force and economic prosperity, and 15 indices. The combination weighting of the evaluation indices is conducted with entropy weight method and variance correction G1 weighting method, and the improved TOPSIS method is used to comprehensively evaluate the economic sustainable development of the mining city Liupanshui from 2006 to 2011. The innovation and characteristics of this paper lie in three aspects: firstly, it determines the importance ratio between the indices of Gl weighting method with the ratio of the variance of two adjacent indices, avoids the problems of subjective determination and randomness of importance ratio with Gl weighting method in existing research, and solves the problem of objective distribution of subjective and objective weights; secondly, it improves the TOPSIS method, and changes the distance in the TOPSIS method to the Mahalanobis distance, so that the calculation is simpler; thirdly, it uses the combination weight obtained through the subjective weighting method and objective weighting method. This avoids the double drawbacks that the subjective empowerment method of the existing research cannot reflect the changes of objective conditions, or that the objective weighting method cannot reflect the expert experience.
\end{abstract}

Keywords-mining city; economics sustainable development; index system;combinated weight; comprehensive evaluation

\section{INTRODUCTION}

Currently, there are 426 mining cities in China, and the

*Fund Project: Science and Technology Fund Project of Guizhou Province (No.: QIAN KE HE J ZI [2013] No. 33); Youth Science and Technology Talent Growth Project of Guizhou Provincial Department of Education (No.); Science and Technology Innovation Team of Liupanshui Normal College (No.: LPSSYKJTD201702) Humanities and Social Sciences Research Project of Guizhou Provincial Department of Education (No.: 2016gh03, 2017DXS02, 2015DXS05); Teaching Quality and Teaching Reform Projects of Higher Education Institutions in Guizhou Province (No.: GZSJG10977201603, GZSJG10977201508, GZSJG10977201505, GZSJG10977201608); Major Research Project on Innovating Groups of Guizhou Provincial Department (No.: QIAN KE HE KY ZI [2016] No.056); Excellence Talents Training Program for Mathematics and Applied Mathematics of Guizhou Province (No.: GZSZY10977201401); Scientific Research Project of Liupanshui Normal College (No.: LPSSY201605, LPSSY201313, LPSSYDXS1416, LPSSYDXS1516).

CLC No.: N945.16; F290; F407.1_ Document code: A. local economic development of these cities mainly depends on industrial investment oriented by mineral resources development. With the development of these cities, a series of problems, such as land and water sources pollution, damage to natural environment and regional ecology, have emerged. After these problems arise, some mining cities have successively issued their own solutions, for example, Daqing City developed alternative industries, Baiyin City adhered to the principle of "Three No and Three Mutual" and promoted the overall development of the regional economy, Panzhihua City simultaneously promoted resource development, urban construction and technological progress, Luquan City paid equal attention to the development of mineral resources and environmental protection, and promoted sustainable development of local economy, and Huaibei City improved the ecological environment in mining area. All these transformations were to achieve sustainable development of mining cities. How to achieve sustainable economic development is a subject worthy of study for Liupanshui City as one of the mining cities. Current researches on the economic sustainable development of mining cities are concentrated on the followings: The first is the qualitative research on the sustainable development of mining cities, to offer strategies and recommendations for sustainable development of mining cities, and there are many studies in this area. For example, Li Xianhai takes Tongling City as an example to study the main path for the transformation of Tongling City [1]. Liu Dingyi believes that the ability of city's economic sustainable development has made great progress, but generally lags behind economic globalization and economic development trends, especially not in line with China's economic strength and development potential [2]. The second is the combination of qualitative and quantitative researches, for example: Yu Guang proposes the theory of regional harmonious development and the evaluation index system and standards for mining cities' economic transformation [3]. Based on the theories of sustainable development and innovation, Liu Shuang proposes the model of economic transformation and sustainable development for mining cities [4]. Li Chunmin makes e a comprehensive evaluation of the sustainable economic development of mining cities with BP neural network method [5]. Wei Lianghuan comprehensively evaluates the sustainable economic development of mining 
cities with the entropy method [6]. Liu Dingyi uses the neural network to establish an evaluation model of city economic sustainable development index system [7]. The above researches have certain research significance, however, at the same time, it can be seen that some researches' evaluation systems are complicated with low operability; besides, they basically use the existing methods for evaluation. This paper will establish a reasonable index system of economic sustainable development with reference to the international authoritative institutions and frequently cited domestic literature, conduct combination weighting on indices with entropy weight method and G1 method, and comprehensively evaluate the economic sustainable development of Liupanshui City according to the improved TOPSIS method.

\section{CONSTRUCTION OF EVALUATION SYSTEM}

Based on the sustainable development system of the United Nations Commission on Sustainable Development [8], the UK Sustainable Development Indicator System [9] and some frequently cited domestic literature, with the principles of systematic, feasible, comparable, integral, scientific, easy-toselect and representative, this paper screens indices via principal component analysis, step-by-step analysis and grey correlation, and constructs an evaluation index system for economic sustainable development of mining city including 6 dimensions of economic scale, industrial structure, economic intensiveness, economic extroversion, economic driving force and economic prosperity, and 15 indices, as shown in "Fig. 1".

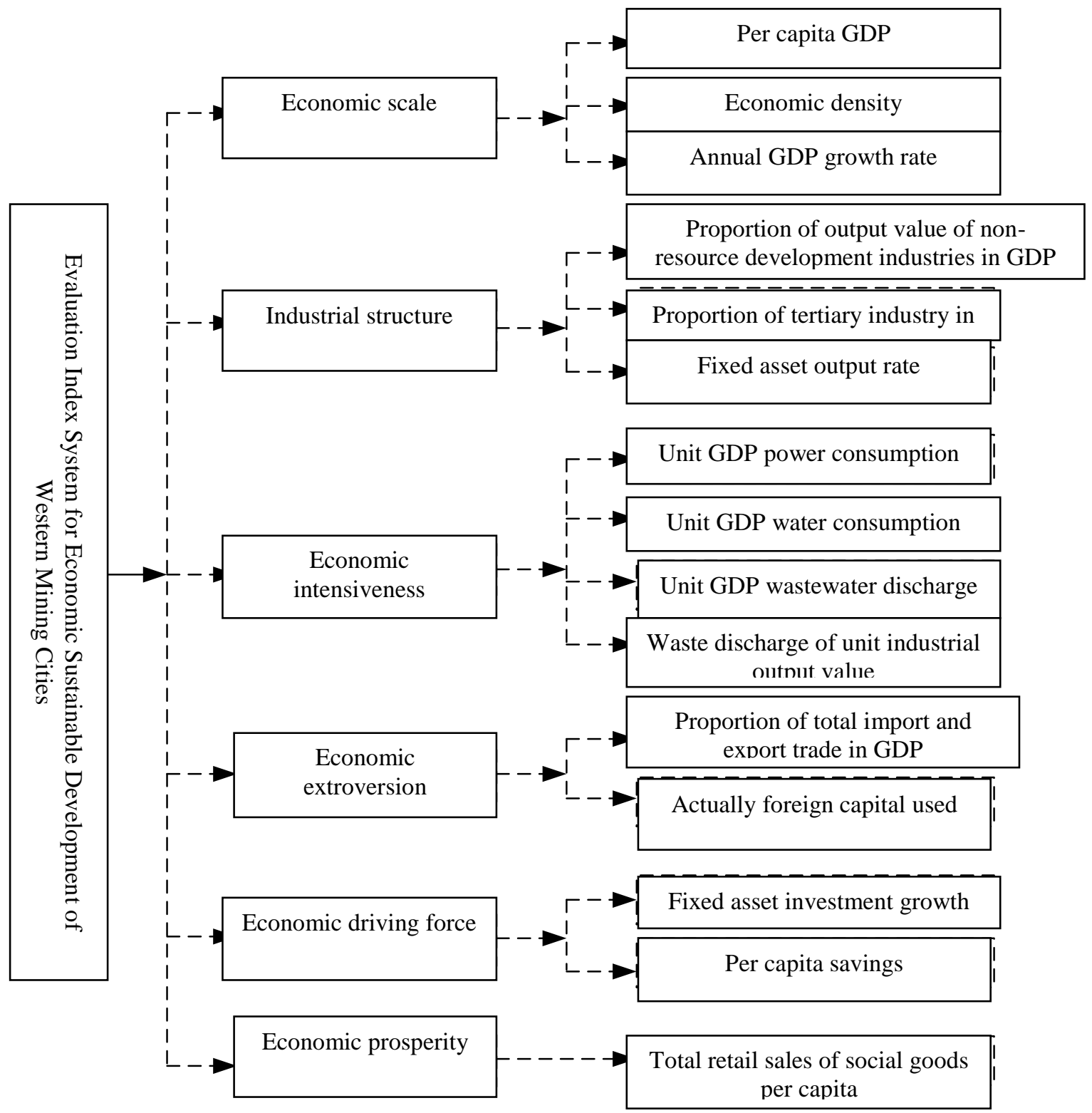

Fig. 1. Evaluation index system for economic sustainable development of western mining cities. 


\section{RESEARCH METHODS}

\section{A. Standardization of Indices}

Set the value of No. ${ }^{j}$ index of No. ${ }^{i}$ evaluated object as $X_{i, j}(i=1,2, \cdots, m ; j=1,2, \cdots, n)$, the original data forms a matrix $X_{m \times n}$ with $m$ rows and $n$ columns. Considering that different indices of the evaluated object always have different dimensions and dimension units, the indices must be standardized.

1) Standardization of positive indices

Set: the value of No. $i$ index No. $i$ year is $X_{i j}(i=1,2, \cdots, m ; j=1,2, \cdots, n)$, the more positive the index, the better, then it is standardized according to the following formula [10], $Y_{i j}$ is

$$
Y_{i j}=\frac{X_{i j}-\min _{1 \leq i \leq m}\left(X_{i j}\right)}{\max _{1 \leq i \leq m}\left(X_{i j}\right)-\min _{1 \leq i \leq m}\left(X_{i j}\right)}(i=1,2, \cdots, m ; j=1,2, \cdots, n)
$$

\section{2) Standardization of negative indices}

Set: the value of No. $i$ index No. $i$ year is $X_{i j}(i=1,2, \cdots, m ; j=1,2, \cdots, n)$ index, the better, then is standardized according to the following formula [10], $Y_{i j}$ is

$$
Y_{i j}=\frac{\max _{1 \leq i \leq m}\left(X_{i j}\right)-X_{i j}}{\max _{1 \leq i \leq m}\left(X_{i j}\right)-\min _{1 \leq i \leq m}\left(X_{i j}\right)}(i=1,2, \cdots, m ; j=1,2, \cdots, n)
$$

\section{3) Standardization of moderate indices}

Set: the value of No. $i$ index No. $i$ year is $X_{i j}(i=1,2, \cdots, m ; j=1,2, \cdots, n)$, the more moderate the index, the better, then it is standardized according to the following formula [10], $Y_{i j}$ is

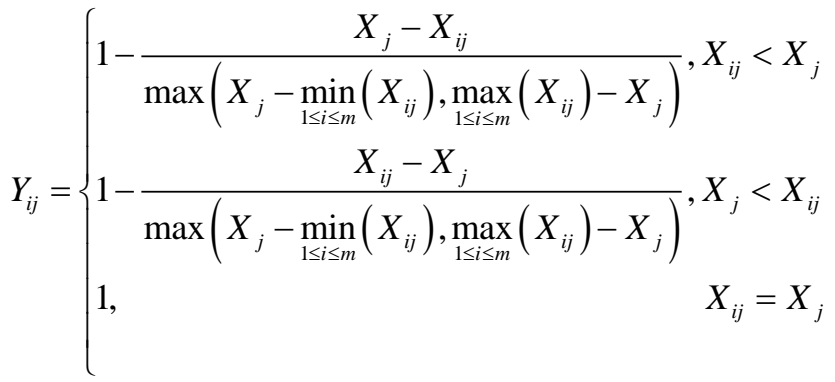

\section{B. Determining Weight with Entropy Weight Method}

Entropy is originally a thermodynamic concept, which was first introduced by C.E. Shannon to information theory. It has now been widely used in engineering technology, social economy and other fields. Entropy can be used to calculate the weight of indices [11], [12], [13, [14]. The specific calculation steps for determining the weight with this method are as follows:

1) Method for determining the entropy value of each index

$$
P_{j}=-K \sum_{i=1}^{m} r_{i j} \operatorname{Ln}\left(r_{i j}\right)
$$

In the formula

$$
r_{i j}=\frac{Y_{i j}}{\sum_{i=1}^{m} Y_{i j}}\left(K=\frac{1}{\operatorname{Ln}(m)} ; j=1,2, \cdots, n\right),
$$

(when $r_{i j}=0, r_{i j} \operatorname{Ln}\left(r_{i j}\right)=0$ )

2) Method for determining the difference coefficient of each index

$$
H_{j}=1-P_{j}
$$

\section{3) Method to determine weight}

The standardization of index difference coefficient can be used to obtain the weight. The calculation formula is:

$$
W_{j}=\frac{H_{j}}{\sum_{j=1}^{n} H_{j}}
$$

C. Determining the Weight with Variance Correction G1 Method [15]

1) Determining the order relationship of the evaluation indices with $\mathrm{Gl}$ method

2) Giving objective assignment of the importance ratio of the adjacent indices ${ }^{x_{k-1}}$ and ${ }^{x_{k}}$ with variance

$$
r_{k}= \begin{cases}\frac{V_{k-1}}{V_{k}} & V_{k-1} \geq V_{k} \\ 1 & V_{k-1}<V_{k}\end{cases}
$$

3) If the objective assignment of ${ }^{r_{k}}$ is given, the weight $\omega_{n}$ of No. ${ }^{n}$ index with ${ }^{G 1}$ method is

$$
\omega_{n}=\left(1+\sum_{k=2}^{n} \prod_{i=k}^{n} r_{i}\right)^{-1}
$$

4) The weight calculation formula for No. ${ }^{n-1, n-2, \cdots, 3,2}$ index obtained based on weight $\omega_{n}$

$$
\omega_{k-1}=r_{k} \omega_{k}, k=n, n-1, \cdots, 3,2
$$


Among them, $\omega_{k-1}$ is the weight of No. $k-1$ evaluation index with $G 1$ method; ${ }^{r}$ is the objective assignment given by the variance ratio of the adjacent indices; ${ }^{\omega_{k}}$ is the weight of No. $k$ evaluation index with $G 1$ method.

$$
\text { Set: }{ }^{\omega_{j}^{z}} \text { is the vector }(j=1,2, \cdots, n) \text { that constitutes the }
$$
weight of the evaluation index with $G 1$ method, then $\omega_{j}^{z}=\left(\omega_{1}, \omega_{2}, \cdots, \omega_{n}\right)$

\section{Determining Weight with Combination Weighting}

Set: $W_{j}^{*}$ is the combined weight of No. ${ }^{j}$ index after combining the two weighting methods, $W_{J}^{*}$ is expressed as a linear combination $(j=1,2, \cdots, n)$ of $W_{j}$ and $\omega_{j}^{z}$, i.e., $W_{j}^{*}=\alpha \omega_{j}^{z}+(1-\alpha) W_{j}$

With the target of the minimum quadratic sum of "deviation between the combined weight and weight with deviation of $G 1$ method" and "deviation between the combined weight and the weight of the entropy method", the target function is established with the calculation method of the minimum value in the mathematical analysis, that is to calculate the partial derivative with ${ }^{W_{j}}$ and $\omega_{j}^{z}$ as unknown quantity, and make the result zero, thereby $\alpha=0.5$, i.e.

$$
W_{j}^{*}=0.5 \omega_{j}^{z}+0.5 W_{j}
$$

It can be seen that the objective weight and subjective weight in the combined weight each account for $50 \%$.

\section{E. Combination Weighting TOPSIS Method [16]}

TOPSIS method, also known as the Technique for Order Preference by Similarity to an Ideal Solution, is a common method for multi-target decision making. The specific steps are as follows:

1) Standardizing the data, establishing a standardized matrix with original data: Standardize the data with equations $(1,2,3)$ and establish a standardized data matrix.
2) Selection of the best and worst solutions: Select the best and worst solutions from the normalized data.

The best solution $y^{+}=\left(y_{1}^{+}, y_{2}^{+}, \mathrm{L}, y_{3}^{+}\right)$; the worst solution $y^{-}=\left(y_{1}^{-}, y_{2}^{-}, \mathrm{L}, y_{3}^{-}\right)$

$y_{j}^{+}=\max \left(Y_{1 j}, Y_{2 j}, \mathrm{~L}, Y_{m j}\right), j=1,2, \mathrm{~L}, n$

where

$y_{j}^{-}=\min \left(Y_{1 j}, Y_{2 j}, \mathrm{~L}, Y_{m j}\right), j=1,2, \mathrm{~L}, n$

3) Determining the distance between the best and worst values of the evaluation index according to the Mahalanobis distance: This method contains less distance calculation steps than that of the original TOPSIS method, which is simpler and worth promoting.

$$
\begin{aligned}
& D_{i}^{+}=\sum_{j=1}^{n} W_{j}^{*}\left|y_{i j}^{\prime}-y_{j}^{+}\right|, i=1,2, \mathrm{~L}, m . \\
& D_{i}^{-}=\sum_{j=1}^{n} W_{j}^{*}\left|y_{i j}^{\prime}-y_{j}^{-}\right|, i=1,2, \mathrm{~L}, m .
\end{aligned}
$$

Distance vector $D^{+}=\left(D_{1}^{+}, D_{2}^{+}, \mathrm{L}, D_{m}^{+}\right)$of the best value; distance vector $D^{-}=\left(D_{1}^{-}, D_{2}^{-}, \mathrm{L}, D_{m}^{-}\right)$of the worst value

4) Calculating the relative closeness of each target:

$$
C_{i}=D_{i}^{-} /\left(D_{i}^{-}+D_{i}^{+}\right), i=1,2, \mathrm{~L}, m \text {. }
$$

The larger $C_{i}$, the closer the evaluated target is to the best level, the better the target; otherwise the worse. The targets are sorted according to the relative closeness to form a decision basis.

\section{CASE ANALYSIS}

\section{A. Original Data}

According to Guizhou Statistical Yearbook and the China City Statistical Yearbook of 2006-2011, the index data in the evaluation system is sorted out, and the original data is shown in "Table I". 
TABLE I. ORIGINAL Data of EVALUATION INDICES OF ECONOMIC SUSTAINABLE DEVELOPMENT

\begin{tabular}{|c|c|c|c|c|c|c|c|c|c|}
\hline & $\begin{array}{c}\text { Criteria } \\
\text { Layer }\end{array}$ & Index Layer & Index Description & 2006 & 2007 & 2008 & 2009 & 2010 & 2011 \\
\hline \multirow{15}{*}{ 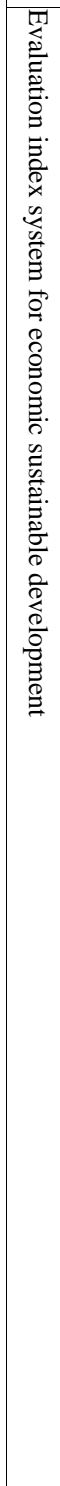 } & \multirow{3}{*}{$\begin{array}{l}\text { Economic } \\
\text { scale }\end{array}$} & $\begin{array}{lcc}\begin{array}{l}\text { Per capita } \\
\text { (yuan/person) }\end{array} & \text { GDP } \\
\end{array}$ & $\begin{array}{l}\text { Reflecting the overall economic } \\
\text { strength of the region (positive) }\end{array}$ & 8530.8 & 10005.7 & 12500 & 1317.3 & 15676.8 & 19084.9 \\
\hline & & $\begin{array}{l}\text { Economic density } \\
(10000 / \mathrm{km} 2)\end{array}$ & $\begin{array}{l}\text { Reflecting the land economic } \\
\text { benefits of the region (positive) }\end{array}$ & 255.71 & 303.21 & 389.55 & 415.96 & 504.99 & 618.71 \\
\hline & & $\begin{array}{l}\text { Annual GDP growth } \\
\text { rate }(\%)\end{array}$ & $\begin{array}{l}\text { Reflect the macroeconomic } \\
\text { conditions of the region (positive) }\end{array}$ & 18 & 15.7 & 14.9 & 11.5 & 15.8 & 16.6 \\
\hline & \multirow[t]{3}{*}{$\begin{array}{l}\text { Industrial } \\
\text { structure }\end{array}$} & $\begin{array}{l}\text { Proportion of output } \\
\text { value of non- } \\
\text { resource } \\
\text { development } \\
\text { industries in GDP } \\
(\%)\end{array}$ & $\begin{array}{l}\text { Reflect the dependence of } \\
\text { resource-based cities on resource } \\
\text { development industries (positive) }\end{array}$ & 43.1 & 41.11 & 41.49 & 36.95 & 39.26 & 37.33 \\
\hline & & $\begin{array}{ll}\text { Proportion } & \text { of } \\
\text { tertiary industry in } & \text { in } \\
\text { GDP }(\%) & \\
\end{array}$ & $\begin{array}{l}\text { Reflect the overall level of } \\
\text { economic development (positive) }\end{array}$ & 34.1 & 33.07 & 34.27 & 30.78 & 33.1 & 32.11 \\
\hline & & $\begin{array}{l}\text { Fixed asset output } \\
\text { rate }(\%)\end{array}$ & $\begin{array}{l}\text { Reflect the status quo of regional } \\
\text { economic development (positive) }\end{array}$ & 1.226 & 1.31 & 1.91 & 1.48 & 2.84 & 1.63 \\
\hline & \multirow{4}{*}{$\begin{array}{l}\text { Economic } \\
\text { intensiven } \\
\text { ess }\end{array}$} & $\begin{array}{l}\text { Unit GDP power } \\
\text { consumption }(\mathrm{kw} / \mathrm{h})\end{array}$ & \multirow{4}{*}{$\begin{array}{l}\text { Reflect the ability to transform } \\
\text { economic growth patterns and } \\
\text { optimize industrial structure } \\
\text { (negative) }\end{array}$} & 168011 & 249342 & 218460 & 216418 & 326696 & 293428 \\
\hline & & $\begin{array}{l}\begin{array}{l}\text { Unit GDP water } \\
\text { consumption }(10000 \\
\text { tons) }\end{array} \\
\end{array}$ & & 2954 & 2871 & 4312 & 3469 & 2168 & 3217 \\
\hline & & $\begin{array}{lr}\text { Unit } & \text { GDP } \\
\text { wastewater } & \\
\text { discharge } & (10000 \\
\text { tons }) & \\
\end{array}$ & & 3577 & 4457 & 2680 & 3177 & 3932 & 4959 \\
\hline & & $\begin{array}{l}\text { Waste discharge of } \\
\text { unit industrial output } \\
\text { value (tons/10000) } \\
\end{array}$ & & 0.025 & 0.02 & 0.058 & 0.037 & 0.032 & 0.024 \\
\hline & \multirow{2}{*}{$\begin{array}{l}\text { Economic } \\
\text { extroversi } \\
\text { on }\end{array}$} & $\begin{array}{l}\text { Proportion of total } \\
\text { import and export } \\
\text { trade in GDP (\%) }\end{array}$ & $\begin{array}{l}\text { Reflect whether the region is } \\
\text { engaged in export-oriented } \\
\text { economy and market economy } \\
\text { (positive) }\end{array}$ & 5.8 & 9.3 & 8.7 & 6.2 & 15.1 & 43.3 \\
\hline & & \begin{tabular}{|lr} 
Actually r red & used \\
foreign & capital \\
$(10000$ USD) & \\
\end{tabular} & $\begin{array}{l}\text { Reflect the level of foreign capital } \\
\text { utilization (positive) }\end{array}$ & 1872 & 250 & 1040 & 5500 & 703 & 2982 \\
\hline & \multirow{2}{*}{$\begin{array}{l}\text { Economic } \\
\text { driving } \\
\text { force }\end{array}$} & $\begin{array}{lr}\begin{array}{l}\text { Fixed } \\
\text { investment } \\
\text { rate }(\%)\end{array} & \text { asset } \\
\text { growth }\end{array}$ & $\begin{array}{l}\text { Reflect the scale, speed, } \\
\text { proportional relationship and } \\
\text { direction of use of fixed assets } \\
\text { (positive) }\end{array}$ & 37.94 & 32.53 & 15.78 & 13.9 & 19.23 & 17.47 \\
\hline & & $\begin{array}{l}\begin{array}{l}\text { Per capita savings } \\
\text { (yuan) }\end{array} \\
\end{array}$ & $\begin{array}{l}\begin{array}{l}\text { Reflect the level of wealth } \\
\text { (positive) }\end{array} \\
\end{array}$ & 3262.11 & 3692.31 & $\begin{array}{l}4121.6 \\
5\end{array}$ & 3886.68 & 5851.45 & 8243.8 \\
\hline & $\begin{array}{l}\text { Economic } \\
\text { prosperity }\end{array}$ & $\begin{array}{l}\text { Total retail sales of } \\
\text { social goods per } \\
\text { capita (yuan) }\end{array}$ & $\begin{array}{l}\text { Reflect people's material and } \\
\text { cultural living standards in a } \\
\text { certain period of time (positive) }\end{array}$ & 1953.85 & 2216.24 & $\begin{array}{l}2511.3 \\
3\end{array}$ & 2997.27 & 3471.97 & 4903.76 \\
\hline
\end{tabular}

\section{B. Standardized Data and Index Weights}

According to the original data in "Table I", the standardized data and entropy weights, G1 method weights and combined weights of each index can be calculated by using equations (1)-(9) in the text, as shown in "Table II". 
TABLE II. STANDARDIZEd DATA AND WEIGHTS FOR THE EVALUATION INDICES OF ECONOMIC SUSTAINABLE DEVELOPMENT

\begin{tabular}{|c|c|c|c|c|c|c|c|c|c|c|c|c|}
\hline & $\begin{array}{c}\text { Criteria } \\
\text { Layer }\end{array}$ & Index Layer & Index Description & 2006 & 2007 & 2008 & 2009 & 2010 & 2011 & $\begin{array}{l}\text { Entropy } \\
\text { Weights }\end{array}$ & $\begin{array}{c}\text { G1 } \\
\text { Method } \\
\text { Weights } \\
\text { And }\end{array}$ & $\begin{array}{c}\text { Combined } \\
\text { Weights }\end{array}$ \\
\hline \multirow{16}{*}{ 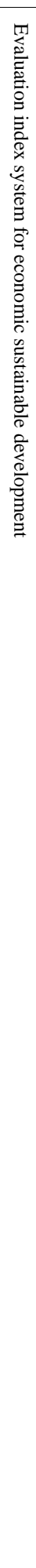 } & \multirow{3}{*}{$\begin{array}{l}\text { Economic } \\
\text { scale }\end{array}$} & $\begin{array}{l}\text { Per capita GDP } \\
\text { (yuan/person) }\end{array}$ & $\begin{array}{l}\text { Reflecting the } \\
\text { overall economic } \\
\text { strength of the } \\
\text { region (positive) }\end{array}$ & 0.4060 & 0.4890 & 0.6294 & 0.0000 & 0.8082 & 1.0000 & 0.0590 & 0.0984 & 0.0787 \\
\hline & & $\begin{array}{l}\text { Economic } \\
\text { density } \\
(10000 / \mathrm{km} 2)\end{array}$ & $\begin{array}{l}\text { Reflecting the land } \\
\text { economic benefits } \\
\text { of the region } \\
\text { (positive) }\end{array}$ & 0.0000 & 0.1309 & 0.3687 & 0.4415 & 0.6867 & 1.0000 & 0.0519 & 0.0984 & 0.0751 \\
\hline & & $\begin{array}{l}\text { Annual GDP } \\
\text { growth rate }(\%)\end{array}$ & $\begin{array}{l}\text { Reflect the } \\
\text { macroeconomic } \\
\text { conditions of the } \\
\text { region (positive) }\end{array}$ & 1.0000 & 0.6462 & 0.5231 & 0.0000 & 0.6615 & 0.7846 & 0.0681 & 0.0832 & 0.0757 \\
\hline & $\begin{array}{l}\text { Criteria } \\
\text { Layer }\end{array}$ & Index Layer & Index Description & 2006 & 2007 & 2008 & 2009 & 2010 & 2011 & $\begin{array}{l}\text { Entropy } \\
\text { Weights }\end{array}$ & $\begin{array}{c}\text { G1 } \\
\text { Method } \\
\text { Weights } \\
\text { And }\end{array}$ & $\begin{array}{c}\text { Combined } \\
\text { Weights }\end{array}$ \\
\hline & \multirow{3}{*}{$\begin{array}{l}\text { Industrial } \\
\text { structure }\end{array}$} & $\begin{array}{ll}\text { Proportion } & \text { of } \\
\text { output value } & \text { of } \\
\text { non-resource } & \\
\text { development } & \\
\text { industries } & \text { in } \\
\text { GDP }(\%) & \end{array}$ & $\begin{array}{l}\text { Reflect the } \\
\text { dependence of } \\
\text { resource-based } \\
\text { cities on resource } \\
\text { development } \\
\text { industries (positive) }\end{array}$ & 1.0000 & 0.6764 & 0.7382 & 0.0000 & 0.3756 & 0.0618 & 0.0736 & 0.0832 & 0.0784 \\
\hline & & $\begin{array}{l}\text { Proportion of } \\
\text { tertiary industry } \\
\text { in GDP }(\%)\end{array}$ & $\begin{array}{l}\text { Reflect the overall } \\
\text { level of economic } \\
\text { development } \\
\text { (positive) }\end{array}$ & 0.9513 & 0.6562 & 1.0000 & 0.0000 & 0.6648 & 0.3811 & 0.0799 & 0.0734 & 0.0766 \\
\hline & & $\begin{array}{l}\text { Fixed asset } \\
\text { output rate }(\%)\end{array}$ & $\begin{array}{l}\text { Reflect the status } \\
\text { quo of regional } \\
\text { economic } \\
\text { development } \\
\text { (positive) }\end{array}$ & 0.0000 & 0.0520 & 0.4238 & 0.1574 & 1.0000 & 0.2503 & 0.0613 & 0.0713 & 0.0663 \\
\hline & \multirow{4}{*}{$\begin{array}{l}\text { Economic } \\
\text { intensiveness }\end{array}$} & $\begin{array}{l}\text { Unit GDP power } \\
\text { consumption } \\
(\mathrm{kw} / \mathrm{h})\end{array}$ & \multirow{4}{*}{$\begin{array}{l}\text { Reflect the ability to } \\
\text { transform economic } \\
\text { growth patterns and } \\
\text { optimize industrial } \\
\text { structure (negative) }\end{array}$} & 1.0000 & 0.4875 & 0.6821 & 0.6949 & 0.0000 & 0.2096 & 0.0578 & 0.0688 & 0.0633 \\
\hline & & $\begin{array}{l}\text { Unit GDP water } \\
\text { consumption } \\
\text { (10000 tons) }\end{array}$ & & 0.6334 & 0.6721 & 0.0000 & 0.3932 & 1.0000 & 0.5107 & 0.0506 & 0.0580 & 0.0543 \\
\hline & & $\begin{array}{l}\text { Unit GDP } \\
\text { wastewater } \\
\text { discharge }(10000 \\
\text { tons) }\end{array}$ & & 0.6064 & 0.2203 & 1.0000 & 0.7819 & 0.4506 & 0.0000 & 0.0582 & 0.0580 & 0.0581 \\
\hline & & $\begin{array}{l}\text { Waste discharge } \\
\text { of unit industrial } \\
\text { output value } \\
\text { (tons/10000) }\end{array}$ & & 0.8684 & 1.0000 & 0.0000 & 0.5526 & 0.6842 & 0.8947 & 0.0947 & 0.0572 & 0.0759 \\
\hline & \multirow[t]{2}{*}{$\begin{array}{l}\text { Economic } \\
\text { extroversion }\end{array}$} & $\begin{array}{l}\text { Proportion of } \\
\text { total import and } \\
\text { export trade in } \\
\operatorname{GDP}(\%)\end{array}$ & $\begin{array}{l}\text { Reflect whether the } \\
\text { region is engaged in } \\
\text { export-oriented } \\
\text { economy and } \\
\text { market economy } \\
\text { (positive) }\end{array}$ & 0.0000 & 0.0933 & 0.0773 & 0.0107 & 0.2480 & 1.0000 & 0.0943 & 0.0572 & 0.0757 \\
\hline & & $\begin{array}{l}\text { Actually used } \\
\text { foreign capital } \\
(10000 \text { USD) }\end{array}$ & $\begin{array}{l}\text { Reflect the level of } \\
\text { foreign capital } \\
\text { utilization (positive) }\end{array}$ & 0.3090 & 0.0000 & 0.1505 & 1.0000 & 0.0863 & 0.5204 & 0.0571 & 0.0532 & 0.0552 \\
\hline & \multirow[t]{2}{*}{$\begin{array}{l}\text { Economic } \\
\text { driving force }\end{array}$} & $\begin{array}{l}\text { Fixed asset } \\
\text { investment } \\
\text { growth rate }(\%)\end{array}$ & $\begin{array}{l}\text { Reflect the scale, } \\
\text { speed, proportional } \\
\text { relationship and } \\
\text { direction of use of } \\
\text { fixed assets } \\
\text { (positive) }\end{array}$ & 1.0000 & 0.7750 & 0.0782 & 0.0000 & 0.2217 & 0.1485 & 0.0750 & 0.0532 & 0.0641 \\
\hline & & $\begin{array}{l}\text { Per capita } \\
\text { savings (yuan) }\end{array}$ & $\begin{array}{l}\text { Reflect the level of } \\
\text { wealth (positive) }\end{array}$ & 0.0000 & 0.0864 & 0.1725 & 0.1254 & 0.5198 & 1.0000 & 0.0652 & 0.0448 & 0.0550 \\
\hline & $\begin{array}{l}\text { Economic } \\
\text { prosperity }\end{array}$ & $\begin{array}{l}\text { Total retail sales } \\
\text { of social goods } \\
\text { per capita (yuan) }\end{array}$ & $\begin{array}{l}\text { Reflect people's } \\
\text { material and cultural } \\
\text { living standards in a } \\
\text { certain period of } \\
\text { time (positive) }\end{array}$ & 0.0000 & 0.0889 & 0.1890 & 0.3537 & 0.5146 & 1.0000 & 0.0532 & 0.0415 & 0.0474 \\
\hline
\end{tabular}




\section{Closeness of Calculating Target}

According to the improved TOPSIS method, that is, the best distance and worst distances are calculated based on formulas (10) and (11), and the closeness of economic sustainable development in each year from 2006 to 2011 is calculated based on formula (12), thereby obtaining the ranking of economic sustainable development, in turn, the economic sustainable development of the western mining city, Liupanshui is analyzed, and the closeness is shown in "Table III".
TABLE III. THE ClOSENESS OF ECONOMIC SUSTAINABLE DEVELOPMENT IN EACH YEAR FROM 2006 TO 2011

\begin{tabular}{|l|c|c|r|r|r|c|}
\hline & $\mathbf{2 0 0 6}$ & $\mathbf{2 0 0 7}$ & $\mathbf{2 0 0 8}$ & $\mathbf{2 0 0 9}$ & $\mathbf{2 0 1 0}$ & $\mathbf{2 0 1 1}$ \\
\hline $\begin{array}{l}\text { Worst } \\
\text { distance }\end{array}$ & 0.5390 & 0.4258 & 0.4184 & 0.2760 & 0.5352 & 0.5892 \\
\hline $\begin{array}{l}\text { Best } \\
\text { distance }\end{array}$ & 0.4610 & 0.5742 & 0.5816 & 0.7240 & 0.4648 & 0.4108 \\
\hline Closeness & 0.5390 & 0.4258 & 0.4184 & 0.2760 & 0.5352 & 0.5892 \\
\hline Ranking & 2 & 4 & 5 & 6 & 3 & 1 \\
\hline
\end{tabular}

According to the ranking of economic sustainable development in "Table III", we can visually see from "Fig. 2".

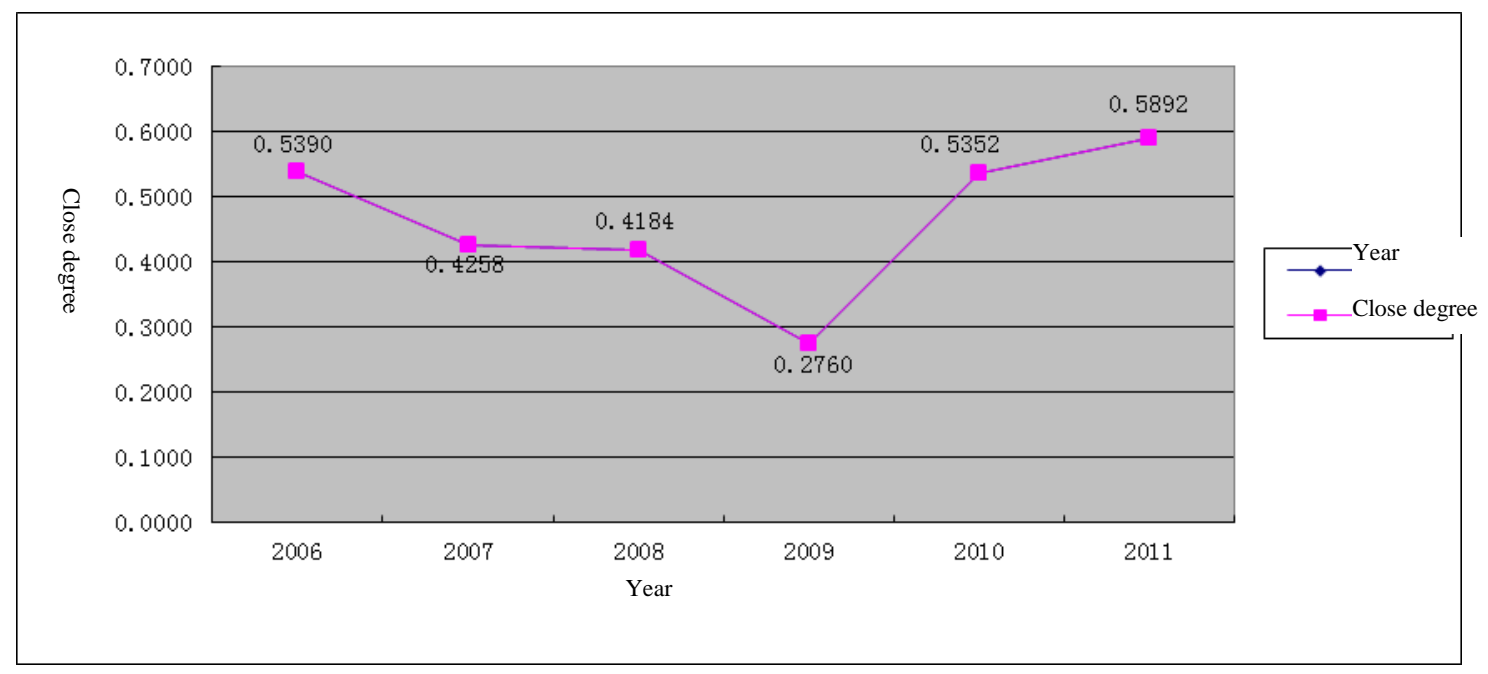

Fig. 2. Changes in the economic sustainable development of Liupanshui from 2006 to 2011

\section{ANALYSIS OF ECONOMIC SUSTAINABLE DEVELOPMENT}

\section{A. The Overall Situation of Sustainable Economic \\ Development}

From the ranking of the closeness of economic sustainable development from 2006 to 2011 in Table 3, it can obtain the ranking of sustainable economic development in each year from 2006 to 2011 as follows: 2011f 2006f $2010 \mathrm{f} 2007 \mathrm{f} 2008 \mathrm{f} 2009$. It can be seen that the economic sustainable development of the western mining city, Liupanshui, fell from 2006 to 2009, and then rose year by year after that.

\section{B. Analysis of the Volatility of Economic Sustainable Development}

Liupanshui is generally considered to be sustainable from the economic development index system. However, it also has serious problems. The proportion of non-resource development industry's output value to GDP is almost at a constant level. In 2009 , it was even relatively falling, which shows that it has little effect in the economic development system, so the single economic structure of Liupanshui City is still a problem that we must face.

\section{The Industrial Structure Is Single}

Since the establishment of the city, Liupanshui has had problems such as a single economic and industrial structure, congenital inadequacies in urban service functions and basic construction. Due to the long-term dependence on the advantages of local mineral resources, the single industrial structure has complicated the internal system, and the development of emerging industries is limited by the development of Liupanshui's mineral resources industry to a certain extent. From an economic perspective, Liupanshui City is currently unable to break away from mining, which is a pillar industry, which has thus caused certain difficulties to the transformation of the economic structure.

\section{CONCLUSION}

This paper makes a comprehensive evaluation of the economic sustainable development of a western mining city, Liupanshui, and has done some work mainly from the following aspects.

- Construct an index system for the sustainable development of mining cities including 6 dimensions of economic scale, industrial structure, economic intensiveness, economic extroversion, economic driving force and economic prosperity.

- Improve the TOPSIS method, change the distance in the TOPSIS method to the Mahalanobis distance, and simplify the calculation.

- Take the entropy weight method of objective weighting method and G1 method of the subjective weighting method to combine the weights of the indices, especially correct the G1 method with variance, so that the index weighting is more objective. 
It is better to take the improved TOPSIS method to make a comprehensive evaluation of the economic sustainable development of Liupanshui from 2006 to 2011.

- Through the understanding of the current situation and general situation of Liupanshui, and a relatively complete analysis of the economic sustainable development of Liupanshui, the research has found that economic sustainable development is not in a stable state.

\section{REFERENCES}

[1] Li Xianhai, Zhou Jinsheng, Xie Shenyan. Evaluation of the Path and Effect of Resource-exhausted Cities' Transformation: Taking Tongling City as an Example [J]. China Mining Magazine, 2014, 23(2): 8-10.

[2] Liu Dingyi. Discussion on the Evaluation of Cities' Urban Economic Sustainable Development Ability [J].Journal of Guangxi Institute of Socialism,2008,19(1):74-76.

[3] Yu Guang. Research on Economic Transformation Theory and Evaluation Method of Mining Cities [D]. Beijing: China University of Geosciences, 2007.

[4] Liu Shuang. Research on Economic Transformation Theory and Evaluation Method of Mining Cities [D]. Beijing: China University of Geosciences, 2006.

[5] Li Chunmin, Li Kerong, Wang Yunhai. Comprehensive Evaluation Model for Sustainable Development of Mining Cities Based on BP Neural Network Method [J].China Mining Magazine,2006,15(9):25-28.

[6] Wei Lianghuan, Dong Linlin. Study of Sustainable Development of Mining Cities Based on Entropy Method - Taking Tongchuan City, Shaanxi Province as an Example [J].Journal of Ningxia Teachers College (Natural Science),2009,30(3):54-58.

[7] Liu Dingyi. Analysis on the Evaluation Model of City Economic Sustainable Development Index System [J].Journal of Guangzhou University (Social Science Edition),2008,7(3):17-21.

[8] World Commission on Environment and Development(WCED ).The B rundtland Report,Our Common Future[M].Oxford:Oxford University Press, 1987.

[9] Government Statistic Office of UK.Indicators of sustainable development for the United Kingdom [M].London:HM SO Publications center, 1996.

[10] Guo Yajun. Comprehensive Evaluation Theory, Method and Application [M] Beijing: Science Press, 2007: 49-51.

[11] Xie Chi, Zhong Zan. Application of Entropy Method in Comprehensive Evaluation of Banking Performance [J]. China Soft Science, 2002, (9): 108-110.

[12] Guan Xiaoyu. Analysis of Bank Profitability Based on Entropy Method [J]. Modern Business and Industry, 2009, (2): 166-167.

[13] Wei Xiaoquan, Xia Yunfeng, Liu Zhaohui. Evaluation of Comprehensive Competitiveness of Chain Drug Stores Based on Entropy Weight Method [J].Statistics and Decision,2009,(15):169170.

[14] Zhou Chaomin, Geng Yanbo. Evaluation of Business Performance of Commercial Banks Based on Entropy Method [J]. Shanghai Management Science,2008,(6):9-10.

[15] Chi Guotai, Zhu Zhichuan, Zhang Yuling. Science and Technology Evaluation Model and Empirical Research Based on Entropy Weight-G1 Method [J]. Science Research,2008,26(6):1210-1220.

[16] Lin Haibin. Application of TOPSIS Method in Social Science Achievements Evaluation [J]. Statistics and Decision,2007,(2):5758
[17] Statistics Bureau of the People's Republic of China. Guizhou Statistical Yearbook 2006-2011 [M]. Beijing: China Statistics Press, 2006-2011.

[18] Statistics Bureau of the People's Republic of China. China City Statistical Yearbook 2006-2011 [M]. Beijing: China Statistics Press, 2006-2011. 